\title{
Strategic Actions to Environmental Changes: Act Ahead or React Upon?
}

\author{
Jai Joon Lee ${ }^{1} \&$ Seung B. Bach ${ }^{1}$ \\ ${ }^{1}$ College of Business Administration, California State University, Sacramento, CA, USA \\ Correspondence: Jai Joon Lee, College of Business Administration, California State University, Sacramento, CA, \\ USA. Tel: 1-916-278-7105. E-mail: jlee@csus.edu
}

\author{
Received: May 5, 2017 Accepted: May 27, 2017 Online Published: August 3, 2017 \\ doi:10.5539/jms.v7n3p12 URL: http://doi.org/10.5539/jms.v7n3p12
}

\begin{abstract}
This study investigates how firms proactively or reactively launch (Venkatraman \& Prescott, 1990) their strategic actions in response to environmental changes, particularly to deregulatory and technological changes. Strategic initiatives including mergers and acquisitions to deal with firms' uncertain competitive environments have been regarded as key strategic actions. This study analyzes the nature of firms' willingness to take strategic actions in response to the key environmental changes in the telecom service industry. The natures of environmental changes, broadly defined as deregulatory and technological changes in this research's domain, trigger firms to take on strategic actions both proactively and reactively.
\end{abstract}

Keywords: strategic actions, environmental changes, proactive actions, reactive actions

\section{Introduction}

This study investigates how firms adjust (Venkatraman \& Prescott, 1990) their strategic actions in response to environmental changes, particularly to deregulatory and technological changes. Strategic initiatives, such as strategic partnerships and corporate mergers and acquisitions to deal with firms' uncertain competitive environments have been frequently regarded as key strategic actions. The question of what are antecedents of firms' strategic actions has been one of central research domain in the field of strategic management (Nadkarni $\&$ Barr, 2008). This study focuses on nature of firms' willingness to take strategic actions in response to the key environmental changes in the telecom service industry. For conducting an empirical research, this study hypothesizes that environmental changes, broadly defined as deregulatory and technological changes, trigger firms to take on strategic actions both proactively and reactively.

Due to the lengthy deregulatory processes (Kim \& Prescott, 2005) and the extensive nature of infrastructure investment decisions during the process, incumbents in the telecom service industry are better equipped with appropriate strategic actions in adapting to deregulatory changes. It means that incumbents tend to be preemptive on, to great extents, incoming regulatory changes. On the other hand, in the event of technological changes which constantly evolve to more advanced levels, incumbents are inclined to exploit the already invested technologies before they actually commit themselves to any upcoming new technologies. As a result, incumbents are more reactive in adapting to technological changes. Furthermore, investing on new infrastructure such as telecom networks requires firms to take significant times to vest on new technological standards. As a result, incumbents take their strategic actions rather reactively until new technological changes are fully acknowledged in the market.

The empirical setting in this study is the US telecom industry from 1994 to 2004 . During these times, the industry has experienced major environmental changes driven by a series of deregulatory events and the proliferation of new telecommunication technology services. All these environmental changes have redefined the fast-growing industry structure and competition, and reshuffled the key industry players tremendously. Also, service convergences between telecom and broadcasting sectors made the industry boundaries more ambiguous and complex. Consequently all of these major environmental changes lowered entry barriers and caused strategic challenges to various service providers. In response to these changes, key telecom service providers have taken various strategic actions, including mergers and acquisitions and strategic alliances. Generalizing from the above industry events, this study investigates that the nature (proactiveness vs. reactiveness) of a firm's strategic actions will be determined by the fact that environmental changes are driven either by deregulatory or 
technological initiatives.

\section{Literature Review}

Environmental changes promote organizational transformation by redrawing industry boundaries, shifting the scope of permissible strategic activities for incumbents and new entrants, and changing incentives for certain strategic behaviors (Delmas \& Russo, 2005; Miller \& Chen, 1994). On the other hand, the choice of strategic actions initiated by organizations will constrain the way the environment unfolds. The firm's ability to select the right mix of strategic actions in a dynamic environmental condition can be a very powerful tool to outperform others. Several theoretical frameworks covering such interactions with different assumptions will be surveyed.

Insights from industrial organization (IO) economics have been extremely important in developing strategic management models of how a firm achieves sustainable competitive advantage (Grimm et al., 2006). IO economics provides direct insights into how firms can obtain competitive advantages through strategic positioning in the context of industry structure and pursuing strategies that are appropriate to specific industry structure (Grimm et al., 2006). IO economics theory argues that a firm's competitive advantage is mainly influenced by industry structure and a firm's strategic actions can be emphasized as the firm's willingness to position the firm's low cost or differentiation strategies within an industry structure (Porter, 1980). Therefore, industry structures have predominantly influenced the natures of strategic decisions.

In case of scale-based industries such as wireless industry, the industry structure would favor the incumbents' leveraging of their market dominance even after deregulatory or technological changes. Representing a more extreme flavor of environmental selection on organizational forms, organizational ecology argues that environmental and market conditions set the stage for certain firms to outperform others by virtue of their market compatibility rather than by their internal efficiency (Carroll, 1993). However, even among incumbents, environmental changes influence each firm's strategic behavior in different ways. Both IO economics and organizational ecology do not explain the heterogeneity of incumbents' strategic behaviors in response to environmental changes.

The strategic choice perspective (Miles \& Snow 1978) argues that strategic adaptation is a dynamic process subject to both managerial actions and environmental forces. It implies that management should take into account the multiple ways that firms can interact with their environments through the process of mutual adaptation between the organization and its environmental domain. Chakravarthy (1991) provided a framework for connecting strategic adaptation to deregulation. Environmental changes, such as deregulatory processes, are important attributes to a firm's choice of strategic behavior since they provide both incumbents and new entrants with asymmetric opportunities and threats. In particular, deregulation that eliminates entry barriers tend to force incumbents to seek for more deterrent activities in order to maintain their current market positions (Grimm \& Smith, 1997). Utilizing a strategic choice perspective, a firm's choice of strategic actions is important in determining the firm's performance in a changing environment.

To further elaborate the dimension of different mix in developing firm's strategic actions, the resource based view of the firm (RBV), an effort to explain competitive advantage as acquiring an ownership of scarce and valuable resources and the firm's manipulating its resources, can be explored (Barney, 1991). Environmental changes require a firm to update a shared set of assumptions about resources, capabilities and objectives. In addition, a firm needs to be more flexible to uncertainties and update a shared set of assumptions about resources and capabilities (Clemons, 1997). A firm's relative strategic position will be affected by the types of strategic actions that a firm implements.

Often times, environmental changes (both deregulatory and technological changes) can be influenced by policy makers in the respective industry setting. For incumbents, they develop their own routines of strategic action behaviors to cope with such environmental changes. Nelson \& Winter (1982) argued that routines were made up of the conscious and tacit knowledge and skills held by firms who carried out certain types of strategic activities more frequently. Levinthal \& March (1993) also argued that a firm's actions tended to be gradually rigid, narrow, and simple owing to the repeated use of their knowledge bases. Once the firm's choice of strategic actions achieves success, their tendency is to continue to exploit their existing strategies that have worked in the past (Audia et al., 2000; Miller, 1994; Miller \& Chen, 1994). In other words, organizational inertia (Hannan \& Freeman, 1984) forces a firm to be less motivated to compete aggressively. This leads a firm to be inattentive to the intelligence gathering and information processing activities (Miller, 1994). Typically, the firm's embeddedness in its institutional context is a basic reason for a firm's resistance to change (Greenwood \& Hinings, 1996). Thus, the more firms are coupled to a prevailing organizational template in a highly structured institutional context, the higher their resistance to change (Greenwood \& Hinings, 1996). However, their 
persistent and repetitive use of certain strategic action type(s) can be hampered when external conditions are changed to require alternative responses, a phenomenon known as a competency trap (Levitt \& March, 1988). Organizational inertia may lead to self-destruction in not acquiring organizational legitimacy when major shifts in competitive, technological, social, and legal conditions impose the need to use new strategic actions in a timely manner (Audia et al., 2000; Reuf, 1997).

\subsection{Proactive vs. Reactive Actions}

As previously explained, prolonged deregulatory processes (Kim \& Prescott, 2005) and the existing firms' strong ties with influential regulatory bodies, incumbents are better equipped with appropriating their strategic actions in adapting to deregulatory changes. Along with deregulatory changes, technological changes are another dimension of environmental change firms should carefully consider for. Dowling et al. (1994) examined how technological changes had affected an industry's structure. Technological changes establish the ground rules of competition and create alternative market behavior (Henderson, 1993). New technology triggers firms to consider strategic action changes (Christensen, 1997). The fast growing diffusions of new services have created a more intense competitive environment. Also, a significant number of firms have made a series of strategic alliances and engaged in significant merger and acquisition activities in order to be technologically innovative in the era of technological convergence.

Siggelkow (2001) suggested that environmental changes could be classified with respect to the impacts they have on the industry landscape. This study applies the similar approach to look at firm's willingness to take strategic actions in response to environmental changes. Based on the extensive literature discussed above, we may argue that firms adapt their strategic actions in response to environmental changes, and successful firms proactively or reactively adapt and frequently redefine their strategic actions in order to maintain their environmental alignment (Venkatraman \& Prescott, 1990). This study will look at some specific hypotheses of a firm's strategic action responses to deregulatory and technological changes.

\subsection{Hypotheses Development}

Hypotheses in this study focus on the different nature of a firm's strategic response positioning to deregulatory and technological changes. Lengthy deregulatory processes (Kim \& Prescott, 2005) and a firm's strong ties to institutional building (Butler \& Carney, 1986) enable firms to identify key issues and to overcome potential competitive risks in response to deregulatory changes. Ultimately, firms in particular for incumbents, will try to turn deregulatory changes to their advantages (Bailey, 1997). For instance, proactively-responding firms in the process of international expansion gain substantial first-mover advantages due to the transient nature of the windows of market opportunity and lengthy regulatory approval processes (Sarkar et al., 1999). On the other hand, technological changes are difficult to predict and often times radical in nature, and incumbents have a tendency to limit a number of strategic actions they consider for technological changes in advance. Incumbents' prior commitment (Ghemawat, 1991) to the existing technologies may also delay a firm's speedy response to the technological changes. Therefore, a firm takes a reactive strategic action positioning in response to technological changes.

\subsubsection{Proactive Strategic Responses to Deregulatory Changes}

Forms of deregulation impact on the speed of adaptation in various internal governance mechanisms (Kim \& Prescott, 2005). Deregulation process in the telecom industry takes a long path to be effective, and firms, in particular for incumbents, play important roles in shaping the scope of deregulatory changes. As a result, a firm will be proactively involved with strategic actions when deregulatory changes occur, and a firm's strategic actions will be increased even prior to the deregulatory events occur. The earlier firms get involved in the process of deregulatory changes, the more strategic influences they will have (Bailey, 1997) as firms generate a mix of strategic actions in advance to strengthen their capabilities (or maintain their market dominance). With incumbents' strong ties to institutional building (Butler \& Carney, 1986), they utilize the opening of policy window, a period when incumbents created the strategic use of information to shape a policy path in their favor (Bailey, 1997; Owen \& Braeutigam, 1978). In other word, incumbents identify the key regulatory issues, overcome potential political difficulties by redrafting proposals, and thereby turn the politically propitious events to their advantages (Bailey, 1997).

Depending upon the nature of deregulatory changes, a firm makes its strategic actions whether certain deregulatory changes create an incentive to join with competitors (improving collective advantages) or to be apart from competitors (improving relative advantages). Thus, a firm sets the stage to what extent deregulatory changes would be unfolded by proactively increasing its strategic actions prior to deregulatory changes became effective. For example, a firm with discernible market power and leadership positions proactively undertakes a 
set of deterrent actions to achieve a competitive advantage (Grimm \& Smith, 1997). Sarkar et al. (1999) argued that proactively-responding firms in the process of international expansion gained substantial first mover advantages due to the transient nature of the policy windows of market opportunity.

\section{Hypothesis 1 All else being equal, when deregulatory changes occur, a firm's strategic actions will be more proactive}

\subsubsection{Reactive Strategic Responses to Technological Changes}

In contrast, a firm has a difficult time predicting how fast technology changes are unfolded and have reconstructed the marketplace. Wireless service operators tend to wait and see what types of technology protocols will be dominating in the industry. As a result, a firm, particularly an incumbent, has limited options of strategic actions it could proactively consider to cope with technological changes. For incumbents, prior commitment (Ghemawat, 1991) to the existing technologies may also delay their responses because changing or even abandoning the existing resources and technological knowledge bases will receive stronger resistance both internally and externally. Unlike new entrants being aggressively innovative to new technologies in the marketplace, incumbents tend to be rather reactive in shifting their strategic actions.

Also, upgrading infrastructure such as telecom networks requires firms to take longer time to install new technological standards. As a result, incumbents tend to take their strategic actions reactively until new technological changes are fully acknowledged in the market. Innovative technological changes may award proactive firms, however, a firm may wait and see what others would respond to technological changes. Since the introduction of wireless telecom services in early 1980s', wireless technologies have undertaken a series of technological evolution from the analogue to the more efficient digital networks. Even among digital wireless technologies, different technology standards were introduced and upgraded in the market. Since it requires lengthy time and extreme amount of resources to deploy any new telecom infrastructure, a firm tends to be more reactive in taking strategic actions to upgrade its technologies when technological changes occur. Also, a firm takes rather conservative approaches in adapting its strategic actions to newer versions of wireless technology standards.

\section{Hypothesis 2 All else being equal, when technological changes occur, a firm's strategic actions will be more reactive}

\section{Method}

The empirical setting in this study is the US telecom industry for the 20-year period between 1984 and 2004. During these times, the US telecom industry has experienced major environmental changes driven by a series of deregulatory events and the introduction of new telecommunication technologies. All these environmental changes have redefined the fast-growing industry structure and competition, and reshuffle the key industry players tremendously. To name a few: AT\&T was divested in 1984; in 1996, the Telecom Act 1934 was revised; wireless and Internet services became more popular with fast-growing number of subscribers and households. Also, convergence between telecom and broadcasting services made the industry boundaries more ambiguous and complex. All of these major environmental changes lowered entry barriers and caused strategic challenges to telecom service providers such as the RBOCs (Regional Bell Operating Companies) to look for main sources of growth. In response to these changes, this study looks at the various strategic actions of key incumbent telecom service providers such as the key RBOCs during the 20-year period between 1984 and 2004. Originally, there were 7 RBOCs that were formed from the 1984 breakup of AT\&T. These are Bell Ameritech, Bell Atlantic, Bell South, Nynex, Pacific Telesis, SBC Communications and US West.

\subsection{Measures}

\subsubsection{Deregulatory Change}

For deregulatory changes in this study, the revision of Telecom Act in 1996 is used. The revision was the most comprehensive deregulatory change that reshaped the telecom industry environment during the 20 year period. The year of 1996 was used as a year of deregulatory changes in this study. For example, it eliminated the regional coverage restrictions and allowed new entrants to serve the basic telecom services. According to Kim \& Prescott (2005), form of deregulatory process in telecom industry was low in pace and scope, therefore, a firm's strategic actions would be considered and executed in multiple-years. To count for such industry characteristics, several time ranges are used as dummy variables. For example, year 1994 (2 year minus from 1996) and year 1998 ( 2 year plus from 1996) are used as \pm 2 year window period to examine if frequency of firms' strategic action portfolios change depending upon different pre- and post-time ranges when environmental changes occur. 


\subsubsection{Technological Change}

Among many other technological changes in this industry, the emergence of wireless technologies is the focus of this study. In the late 1990s, 3G wireless standards became more apparent as the next generation wireless technology in the industry. As a result, key telecom operators began to consider more strategic actions in order to deploy more advanced wireless technologies and services. The year of 2000 was used as a year of technological changes in this study. It was the year when the annual total number of wireless subscribers outnumbered those of the fixed-line telephony subscribers for the first time. It was one of the major technological shifts, showing the signs of increasing growth rate of new telecom technologies and services such as wireless and the high-speed Internet services. To cope with such shifts, telecom operators had to consider modifying their corporate strategic action portfolios in order to sustain their sustainable competitive advantages. Another technological characteristic during the same period is that different communication technologies have begun to converge with each other. To name a few, VoIP (Voice over Internal Protocol) and CATV providers can now serve traditional telephony through different communication platform. Technological convergence forces incumbents (e.g. RBOCs) to formulate their strategic actions by rearranging their resource pools in anticipation of competing against new entrants. Similar to deregulatory change dummy variables, several time ranges are used as technological change dummy variables. For example, year 1998 (2 year minus from 2000) and year 2002 (2 year plus from 2000) are used as \pm 2 year window period to examine if frequency of firms' strategic action portfolios change depending upon different pre- and post-time ranges when technological changes occur.

\subsubsection{Corporate Strategic Actions}

Main variables capturing the level of corporate strategic action in this study are frequency and variety of strategic action portfolios. Measures for these two attributes are adopted from those of Miller \& Chen (1996) and Gnyawali et al. (2006). In addition, some industry-specific and firm-specific control variables are added to control the relationships between a firm's strategic action portfolios and environmental changes. Strategic alliance actions include a broader range of firm's partnering with other firms from equity partnerships to the long term marketing relationships. As long as any RBOCs are involved in the strategic alliance transactions, all of their domestic and foreign alliances are entered into the sample. Mergers and acquisition actions include when any of the seven RBOCs acquire more than $50 \%$ of other firm's total equity (or assets). The same reasoning is applied to divestiture actions when the seven RBOCs divest any of their existing businesses (or assets) to others. In addition, the seven RBOCs' actions are further categorized into firm size (RBOCs vs. non-RBOCs), service scope (SIC 4813 vs. non-SIC 4813) and geographic location (domestic vs. foreign). These detailed categorizations can be applied to code different dimensions of corporate strategic actions. Both the total annual count and the dollar amount measures of corporate strategic actions at their effective date are considered in this study.

\subsubsection{Frequency of Corporate Strategic Action}

Frequency of corporate strategic action portfolios is the total number (or annual dollar values) of a firm's corporate strategic actions in a given year (Miller \& Chen, 1996; Gnyawali et al., 2006). Three major corporate strategic actions - strategic alliance, merger and acquisition, and divestiture actions will be individually counted to measure the frequency of a firm's corporate strategic action portfolios. For some specific strategic actions, it takes more than a year from the announcement of the individual strategic action to the actual effective date. In this study, the effective date of strategic actions is considered for annual action counts. And then, they are summed up in counts and dollar values.

Frequency of corporate strategic action portfolios for firm $\mathrm{i}=\sum \mathrm{N}_{\mathrm{ik}}$ where $N_{i k}$ refers to the number of four corporate strategic actions that firm $i$ undertook in a given year.

\subsubsection{Variety of Corporate Strategic Action}

Variety of corporate strategic action portfolios is the range of strategic actions undertaken by a firm across different corporate strategic actions (Miller \& Chen, 1996; Gnyawali et al., 2006). Gnyawali et al. (2006) defined the competitive variety as the range of actions undertaken by a firm across the various aspects of the value chain. Miller \& Chen (1996) defined the concentration index based on the standard deviation of the standard scores across the 21 types of actions for an airline in a given year, and this standard deviation was standardized by dividing the total number of actions in order to adjust for the firm-size differences (p. 427).

Variety of corporate strategic action portfolios for firm $\mathrm{i}=1-\sum\left(\mathrm{N}_{\mathrm{ij}} / \mathrm{N}_{\mathrm{i}}\right)^{2}$

where $\mathrm{Ni}, j$ is the number of actions in the jth aspect of four corporate strategic actions for firm $i$; thus, (Ni, $j / \mathrm{Ni})$ is the proportion of each corporate strategic actions from the corporate strategic action portfolios for $i$. If firm is 
focusing on a single corporate action type, variety of action portfolios will be close to zero.

\subsubsection{Control Variables}

In order to control potential compounding impacts, the research added several control variables in its testing model. Each RBOC's total asset (tasset) and operating income (opincome) are in use to control their sizes. Also, each RBOC's major serving areas, measured as the number of the top 100 MSAs (Metropolitan Statistical Area) each RBOC serves (wsub), and the number of competitors in each RBOC's region (nrival) are used to control market structures Also, the growth of annual GDP (pcpincome) and annual population (uspop) are included in this study. Summary statistics of each variable are also shown in Table 1.

\subsection{Analytical Method}

Previous research has taken different approaches to study the impact of environmental changes on a firm's strategic actions. The methods includes 1) event study method (Harrison, 2006), 2) case method, 3) event history method, 4) a visual mapping method (Webb \& Pettigrew, 1999), and ANOVA (Elsbach, 19905).

For the impacts of environmental changes on firm's frequency of corporate strategic action portfolios, this study has extensively utilized the dummy variable regression with least squares dummy variables (LSDV) estimator. Since this study focuses on the corporate strategic action portfolios of the seven RBOCs, using the LSDV method is a practical proposition given the need for a small number of dummy variables. In other word, the LSDV estimator is practical only when N is small. In order to use the LSDV estimator, frequency and variety of firms' unique corporate strategic action portfolios are separately converted into the natural logarithm and quadratic forms respectively.

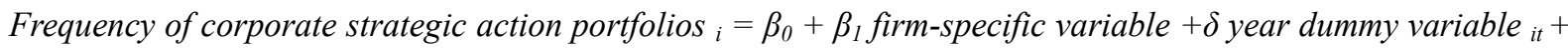
$\varepsilon$

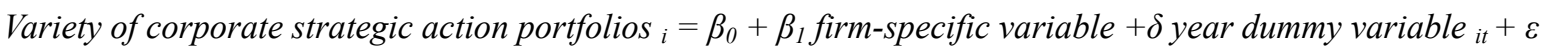

The occurrence of a firm's strategic actions will be proactively frequent even before deregulatory changes occur as tested in H1. On the other hand, the occurrence of a firm's strategic actions will be reactively frequent after technological changes occur as tested in H2. These two hypotheses are tested with the LSDV estimator. To examine a firm's proactiveness vs. reactiveness of strategic actions in response to environmental changes, different time frames with $t \pm 2$ years of deregulatory and technological changes will be considered as dummy variables to see if they show significantly different coefficients in the regression model. In this study, for deregulatory changes, I look at the frequency of corporate strategic action portfolios with $t \pm 2$ year (1994-96 and 1996-98) dummies. For technological changes, another $t \pm 2$ year (1998-2000 and 2000-2002) dummies are taken to compare with the frequency of corporate strategic action portfolios. Both count and dollar measures are used to test these hypotheses.

\section{Results}

For proactive versus reactive strategic responses to environmental changes, a firm's corporate strategic actions tend to be more proactive when deregulatory changes occur, and to be more reactive when technological changes occur. Proactive strategic responses to deregulatory changes are supported in this study. Corporate strategic actions in count measure are more frequent even prior to a change in deregulation. When both pre-event and post-event periods are compared, the standardized coefficient for pre-event period is 5.011 while the standardized coefficient for post-event period is 2.190 when count measure is tested. Even though both coefficients are significant at the $10 \%$ level, the frequency of a firm's corporate actions are twice more likely in the pre-event period. I compare the coefficients of pre-event period with post-event period to test the null

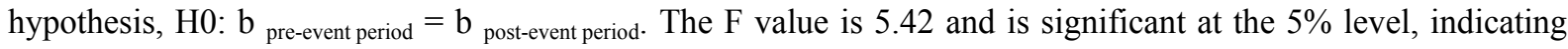
that the coefficient of pre-event period is significantly different from the coefficient of post-event period. The larger coefficient of the pre-event period indicates that a firm's strategic actions will be more proactive when deregulatory changes occur. Frequency of corporate strategic actions in dollar measure shows the meaningful significance when changes in deregulation.

Furthermore, variety of a firm's corporate strategic actions shows consistent results. A firm takes various types of strategic actions proactively even before deregulatory changes occur. Thus, this study finds proactive strategic responses in the variety of a firm's corporate strategic actions when deregulatory changes occur. The significance levels are at the $5 \%$ both in count and dollar measures, but the differences in the coefficients of pre-event and post-event periods are much smaller when variety of a firms' corporate strategic actions are tested in H1. It is due to the fact that several mega-billion dollar M\&A deals have been made just after deregulatory changes in 1996, and these excessive financial commitments have some effects on the significance level. During the pre-1996 
period, a firm has been more flexible with executing different types of corporate strategic actions when count measure is considered.

For H2, this study shows no significance that technological changes have to do with a firm's reactive strategic responses. One interpretation may be that a firm does not take its strategic actions reactively after technological changes occur. Either count or dollar measures are not significant. For the RBOCs, technological changes may not play any significant motivating roles in considering strategic actions reactively.

Table 1. Summary statistics at $10 \%$ significance level

\begin{tabular}{|c|c|c|c|c|c|c|c|c|c|c|c|c|c|c|c|c|}
\hline & Mean & Std. Dev. & allcour $q$ & allvar $\sim$ p & allrea $\sim$ q & allrea $p$ & y9496 & y9698 & y9800 & $\mathrm{y} 0002$ & pcpincome & tasset & opincome & wsub & uspop & nival \\
\hline allcountfreq & 18.343 & 23.455 & 1.0000 & & & & & & & & & & & & & \\
\hline allvarietyp & 39.343 & 27.646 & $-0.1588+$ & 1.0000 & & & & & & & & & & & & \\
\hline allrealfreq & 7113.3 & 16430 & 0.0042 & $0.1883^{*}$ & 1.0000 & & & & & & & & & & & \\
\hline allrealvarı $p$ & 29.511 & 23.458 & $0.3633^{4}$ & $0.5835^{\prime \prime}$ & -0.0274 & 1.0000 & & & & & & & & & & \\
\hline y9496 & 0.1606 & 0.3685 & $0.3909^{*}$ & 0.1240 & -0.0729 & $0.2094^{*}$ & 1.0000 & & & & & & & & & \\
\hline y9698 & 0.1752 & 0.3815 & $0.1592+$ & -0.0374 & 0.1338 & 0.1004 & $0.2168^{*}$ & 1.0000 & & & & & & & & \\
\hline $\mathrm{y} 9800$ & 0.0949 & 0.2941 & 0.0166 & $-0.1454+$ & 0.0864 & -0.0816 & $-0.1416^{+}$ & $0.1784^{*}$ & 1.0000 & & & & & & & \\
\hline $\mathrm{y} 0002$ & 0.0584 & 0.2353 & 0.0057 & -0.0257 & 0.1325 & -0.1339 & -0.1089 & -0.1148 & $0.3442^{*}$ & 1.0000 & & & & & & \\
\hline pcpincome & 21446 & 5527.2 & 0.1055 & 0.0585 & $0.2907^{*}$ & 0.0508 & 0.0896 & $0.2651^{*}$ & $0.2962^{*}$ & $0.2828^{*}$ & 1.0000 & & & & & \\
\hline tasset & 33324 & 31808 & $-0.1420+$ & -0.0591 & $0.2432^{*}$ & $-0.2189^{*}$ & $-0.1658^{*}$ & $-0.1444+$ & 0.0166 & $0.1916^{*}$ & $0.6041^{*}$ & 1.0000 & & & & \\
\hline opincome & 6488.4 & 5503.8 & -0.0953 & -0.0061 & $0.2684^{*}$ & $-0.1676^{*}$ & -0.1238 & -0.0701 & 0.0301 & $0.2146^{*}$ & $0.6241^{*}$ & $0.9646^{*}$ & 1.0000 & & & \\
\hline wsub & $8 \mathrm{E}+06$ & $7 \mathrm{E}+06$ & 0.1340 & 0.0772 & $0.3004^{*}$ & 0.0408 & 0.0948 & $0.2531^{*}$ & $0.4400^{*}$ & $0.3998^{*}$ & $0.8714^{*}$ & $0.5278^{*}$ & $0.5649^{*}$ & 1.0000 & & \\
\hline uspop & 259851 & 16183 & $0.1584+$ & 0.1160 & $0.2438^{*}$ & 0.0963 & 0.0894 & $0.2332^{*}$ & $0.3028^{*}$ & $0.3785^{*}$ & $0.9146^{*}$ & $0.5649^{*}$ & $0.5960^{*}$ & $0.9448^{*}$ & 1.0000 & \\
\hline nrival & 179.44 & 112.08 & $0.1709^{*}$ & -0.0647 & 0.0019 & 0.0000 & 0.0399 & -0.0052 & -0.0205 & $0.2811^{*}$ & $0.3219^{*}$ & $0.5577^{*}$ & $0.5492^{*}$ & $0.4501^{*}$ & $0.5312^{*}$ & 1.0000 \\
\hline
\end{tabular}

Note. * 5\% significance level; $+10 \%$ significance level; (Obs = 111 for SQAllvarietyp and SQAllrealvarietyp).

Table 2. Proactive versus reactive strategic responses to environmental changes (frequency)

\begin{tabular}{|c|c|c|c|c|c|c|c|}
\hline \multirow{2}{*}{\multicolumn{2}{|c|}{$\begin{array}{l}\text { LSDV } \\
\text { Deregulatory } \\
\text { Changes }\end{array}$}} & \multirow{2}{*}{$\begin{array}{l}\text { H1 } \\
\text { Allcountfreq } \\
\text { (count measure) }\end{array}$} & \multirow{2}{*}{$\begin{array}{l}\text { H1 } \\
\text { LNAllrealfreq } \\
\text { (dollar measure) }\end{array}$} & \multicolumn{2}{|l|}{ LSDV } & \multirow{2}{*}{$\begin{array}{l}\mathrm{H} 2 \\
\text { Allcountfreq } \\
\text { (count measure) }\end{array}$} & \multirow{2}{*}{$\begin{array}{l}\mathrm{H} 2 \\
\text { LNAllrealfreq } \\
\text { (dollar measure) }\end{array}$} \\
\hline & & & & \multicolumn{2}{|c|}{ Technological Changes } & & \\
\hline \multirow{2}{*}{ Y9496 } & $\mathrm{t}$ & 4.55 & 3.66 & Y0002 & $\mathrm{t}$ & -0.06 & -0.05 \\
\hline & $\mathrm{P}>[\mathrm{t}]$ & $0.000 * *$ & $0.000^{* *}$ & & $P>[t]$ & 0.950 & 0.964 \\
\hline
\end{tabular}

Note. ** 5\% Significance Level; * 10\% Significance Level.

Table 3. Proactive versus reactive strategic responses to environmental changes (variety)

\begin{tabular}{|c|c|c|c|c|c|c|c|}
\hline \multirow{2}{*}{\multicolumn{2}{|c|}{$\begin{array}{l}\text { LSDV } \\
\text { Deregulatory } \\
\text { Changes } \\
\end{array}$}} & \multirow{2}{*}{$\begin{array}{l}\text { H1 } \\
\text { SQAllvarietyp } \\
\text { (count measure) }\end{array}$} & \multirow{2}{*}{$\begin{array}{l}\text { H1 } \\
\text { SQAllrealvarietyp } \\
\text { (dollar measure) }\end{array}$} & \multicolumn{2}{|l|}{ LSDV } & \multirow{2}{*}{$\begin{array}{l}\mathrm{H} 2 \\
\text { SQAllvarietyp } \\
\text { (count measure) }\end{array}$} & \multirow{2}{*}{$\begin{array}{l}\mathrm{H} 2 \\
\text { SQAllrealvarietyp } \\
\text { (dollar measure) }\end{array}$} \\
\hline & & & & \multicolumn{2}{|c|}{ Technological Changes } & & \\
\hline \multirow[t]{2}{*}{ Y9496 } & $\mathrm{t}$ & 4.24 & 2.85 & 0002 & $\mathrm{t}$ & -1.48 & -1.85 \\
\hline & $\mathrm{P}>[\mathrm{t}]$ & $0.000 * *$ & $0.005 * *$ & & $\mathrm{P}>[\mathrm{t}]$ & 0.143 & $0.068 *$ \\
\hline
\end{tabular}

Note. ** 5\% Significance Level; * 10\% Significance Level.

\section{Discussions and Research Limitation}

Depending upon different pace and scope dimensions of deregulatory changes, a firm's willingness to take any specific strategic actions proactively or reactively will vary. Also, the study should be refined why different statistical results are produced when count and dollar measures are used. For technological changes on the reactiveness of corporate strategic action portfolios, are there any other specific drivers (or events) to impact on the relationship between technological changes and strategic actions? Since the RBOCs are telecom service providers, unlike telecom equipment manufacturers, technological changes may have less direct influences on the reactiveness of corporate strategic actions.

A firm's strategic actions in response to external environmental changes have been largely neglected both by strategic decision makers and scholars. Many firms are repeatedly failed to construct a holistic view of how regulatory and technological changes affect their strategic behaviors (Beardsley et al., 2005). This study 
reiterates the importance of the firm's strategic adaptation mechanism in response to two external environmental changes. Both regulatory and technological changes increasingly shape the structure and conduct of industries and sets in motion major shifts in economic value (Beardsley et al., 2005). Effectively navigating these changing processes could allow incumbents not only to manage risks embedded in regulatory and technological changes better but also to stir their industries and to create potential opportunities for themselves (Beardsley et al., 2005).

The above results should be noted with some interesting implications. First, technological changes can be very complex processes that a firm's choices of considering different corporate strategic actions will be different depending upon the nature of technological changes. For example, Lavie (2006) presented three mechanisms of capability reconfiguration-substitution, evolution, and transformation-that analyzed the incumbents' responses to technological changes. To some extent, the impact of technological changes can be tested on a continuous basis, not as a single event impacting on firms' corporate strategic actions. This argument is very much applicable to the field of telecom service industry since we have experienced a significant amount of technological advancement and convergence during the last decade from 2004 to 2017. It will be worthwhile to replicate this study with the current strategic actions and regulatory and technological initiatives taken from the diverse pool of US Information, Communication, and Technology (ICT) firms of today.

Second, competitive speed refers to how quickly firms act in the event of environmental changes (Nayyar \& Bantel, 1994), and this study looks at the proactive versus reactive responses to deregulatory and technological changes. A firm's capability to act proactively is likely to achieve superior performance (Lee et al., 2000). However, to perform speedy strategic actions, firms should consider additional costs that arise from the potential pitfalls of deciding too early before uncertainty has been adequately resolved or appropriate measures have been taken to guard against unforeseen events (Wernerfelt \& Karnani, 1987). As a result, firms will take reactive responses of their strategic actions to certain environmental changes.

This study shows rather interesting results in regards to a firm's proactive versus reactive responses to environmental changes. Since incumbents (RBOCs in this study) have long history of close ties with the regulators in the US telecom industry, they have better positions to prepare for such deregulatory changes. As a matter of fact, all RBOCs were active participants in numerous policy making forums and the congressional hearings before 1996 Telecom Act was revised and passed in the Congress. Also, lengthy deregulatory process provided them to proactively response to deregulatory changes. The results in this study confirm that a firm's strategic actions (both frequency and variety of corporate strategic action portfolios) will be more proactive when deregulatory changes occur.

On the other hand, when technological changes occur, a firm's strategic actions are not reactive. However, it should be noted that the firm's reactive strategic responses to technological changes are significant when dollar measure is used. Firms will wait and see what others do when technological changes are involved with the likelihood of additional costs associated with executing strategic actions proactively. In particular, significant strategic commitments such as corporate strategic actions in this study will force firms to respond reactively to technological changes.

\section{References}

Audia, P. G., Locke, E. A., \& Smith, K. G. (2000). The Paradox of Success: An Archival and a Laboratory Study of Strategic Persistence Following Radical Environmental Change. Academy of Management Journal, 43(5), 837-853. https://doi.org/10.2307/1556413

Bailey, E. E. (1997). Integrating Policy Trends into Dynamic Advantage. In G. S. Day, D. J. Reibstein, \& R. E. Gunther (Eds.), Wharton on Dynamic Competitive Strategy (pp. 76-98). Hoboken, NJ: John Wiley \& Sons, Inc.

Barney, J. B. (1991). Firm Resources and Sustained Competitive Advantage. Journal of Management, 17(1), 99-120. https://doi.org/10.1177/014920639101700108

Beardsley, S. C., Bugrov, D., \& Enriquez, L. (2005). The Role of Regulation in Strategy. McKinsey Quarterly, 4.

Butler, R. J., \& Carney, M. G. (1986). Strategy and Strategic Choice: the Case of Telecommunications. Strategic Management Journal, 7(2), 161-177. https://doi.org/10.1002/smj.4250070205

Carroll, G. R. (1993). A Sociological View on Why Firms Differ. Strategic Management Journal, 14(4), 237-249. https://doi.org/10.1002/smj.4250140402

Chakravarthy, B. S. (1991). Strategic Adaptation to Deregulation. Journal of Organizational Change Management, 4(1), 22-32. https://doi.org/10.1108/09534819110006193 
Christensen, C. M. (1993). The Rigid Disk Drive Industry: A History of Commercial and Technological Turbulence. Business History Review, 67(4), 531-558. https://doi.org/10.2307/3116804

Clemons, E. K. (1997). Technology-Driven Environmental Shifts and the Sustainable Competitive Disadvantage of Previously Dominant Companies. In G. S. Day, D. J. Reibstein, \& R. E. Gunther (Eds.), Wharton on Dynamic Competitive Strategy, 99-122. Hoboken, NJ: John Wiley \& Sons, Inc.

Delmas, M. A., \& Russo, M. (2005). Deregulation and Resource Reconfiguration in the Electric Utility Industry. Institute for Social, Behavioral, and Economic Research. ISBER Publications. Paper 06. http://repositories .cdlib.org/isber/publications/06 https://doi.org/10.2139/ssrn.699761

Dowling, M. J., Boulton, W. R., \& Elliott, S. W. (1994). Strategies for Change in the Service Sector: The Global Telecommunications Industry. California Management Review, 36(3), 57-88. https://doi.org/10.2307/41165755

Elsbach, K. D. (1994). Managing Organizational Legitimacy in the California Cattle Industry: The Construction and Effectiveness of Verbal Accounts. Administrative Science Quarterly, 39(1), 57-88.

Ghemawat, P. (1991). Commitment: The Dynamic of Strategy. New York: Free Press. https://doi.org/10.2307/2393494

Gnyawali, D. R., He, J., \& Madhavan, R. (2006). Impact of Co-Opetition on Firm Competitive Behavior: An Empirical Examination. Journal of Management, 32(4), 507-530. https://doi.org/10.1177/0149206305284550

Greenwood, R., \& Hinings, C. R. (1996). Understanding Radical Organizational Change: Bringing Together the Old and the New Institutionalism. Academy of Management Review, 21(4), 1022-1054. https://doi.org/10.2307/259163

Grimm, C. M., \& Smith, K. G. (1997). Strategy as Action: Industry Rivalry and Coordination. Cincinnati, Ohio: South-Western College Publishing.

Grimm, C. M., Lee, H., \& Smith, K. G. (2006). Strategy as Action: Competitive Dynamics and Competitive Advantage. Oxford: Oxford University Press.

Hannan, M. T., \& Freeman, J. (1984). Structural Inertia and Organizational Change. American Sociological Review, 49(2), 149-164. https://doi.org/10.2307/2095567

Harrison, D. A. (2006). Regression Models for Predicting Limited Range Dependent Variables, CARMA Consortium Webcast, 2006-2007 Program.

Henderson, R. (1993). Underinvestment and Incompetence as Responses to Radical Innovation: Evidence from the Photolithographic Industry. Rand Journal of Economics, 24(2), 248-270. https://doi.org/10.2307/2555761

Kim, B., \& Prescott, J. E. (2005). Deregulatory Forms, Variations in the Speed of Governance Adaptation and Firm Performance. Academy of Management Review, 30(2), 412-425. https://doi.org/10.5465/amr.2005.16387896

Lavie, D. (2006). Capability Reconfiguration: An Analysis of Incumbent Responses to Technological Change. Academy of Management Review, 31(1), 153-174. https://doi.org/10.5465/amr.2006.19379629

Lee, H., Smith, K. G., Grimm, C. M., \& Schomburg, A. (2000). Timing, Order and Durability of New Product Advantages with Imitation. Strategic Management Journal, 21(1), 23-30. https://doi.org/10.1002/(sici)1097-0266(200001)21:1<23::aid-smj64>3.0.co;2-0

Levinthal, D. A., \& March, J. G. (1993).The Myopia of Learning. Strategic Management Journal, 14(8), 95-112. https://doi.org/10.1002/smj.4250141009

Levitt, B., \& March, J. G. (1988). Organizational Learning. Annual Review of Sociology, 14, 319-340. https://doi.org/10.1146/annurev.soc.14.1.319

Miles, R. E., \& Snow, C. C. (1978). Organizational Strategy, Structure, and Process. New York: McGraw-Hill.

Miller, D. (1994). What Happens After Success: The Perils of Excellence. Journal of Management Studies, 31(3), 325-358. https://doi.org/10.1111/j.1467-6486.1994.tb00621.x

Miller, D., \& Chen, M. J. (1994). Sources and Consequences of Competitive Inertia: A Study of the U.S. Airline Industry. Administrative Science Quarterly, 39(1), 1-23. https://doi.org/10.2307/2393492

Miller, D., \& Chen, M. J. (1996). The Simplicity of Competitive Repertoires: An Empirical Analysis. Strategic 


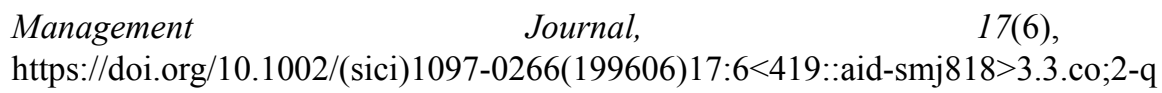

Nadkarni, S., \& Barr, P. S. (2008). Environmental Context, Managerial Cognition, and Strategic Action: An Integrated View. Strategic Management Journal, 29(13), 1395-1427. https://doi.org/10.1002/smj.717

Nayyar, P. R., \& Bantel, K. A. (1994). Competitive Agility: A Source of Competitive Advantage Based on Speed and Variety. Advances in Strategic Management, 10A, 193-227.

Nelson, R. R., \& Winter, S. G. (1982). An Evolutionary Theory of Economic change. Cambridge, Massachusetts: Harvard University Press.

Owen, B. M., \& Braeutigam, R. (1978). The Regulation Game: Strategic Use of the Administrative Process. Cambridge, MA: Ballinger Publishing Company.

Porter, M. (1980). Competitive Strategy: Techniques for Analyzing Industries and Competitors. New York: The Free Press.

Sarkar, M. B., Cavusgil, S. T., \& Aulakh, P. S. (1999). International Expansion of Telecommunication Carriers: The Influence of Market Structure, Network Characteristics, and Entry Imperfections. Journal of International Business Studies, 30(2), 361-381. https://doi.org/10.1057/palgrave.jibs.8490074

Siggelkow, N. (2001). Change in the Presence of Fit: The Rise, The Fall, and The Renaissance of Liz Claiborne. Academy of Management Journal, 44(4), 838-857. https://doi.org/10.2307/3069418

Venkataraman, N., \& Prescott, J. E. (1990). Environment-Strategy Co-Alignment: An Empirical Test of its Performance Implications. Strategic Management Journal, 11(1), 1-23. https://doi.org/10.1002/smj.4250110102

Webb, D., \& Pettigrew, A. (1999). The Temporal Development of Strategy: Patterns in the UK Insurance Industry. Organization Science, 10(5), 601-621. https://doi.org/10.1287/orsc.10.5.601

Werfelt, B., \& Karnani, A. (1987). Competitive Strategy under Uncertainty. Strategic Management Journal, 8(2), 187-194. https://doi.org/10.1002/smj.4250080209

\section{Copyrights}

Copyright for this article is retained by the author(s), with first publication rights granted to the journal.

This is an open-access article distributed under the terms and conditions of the Creative Commons Attribution license (http://creativecommons.org/licenses/by/4.0/). 